\title{
Sanctuaries in Roman Dacia: Materiality and Religious Experience. By Csaba Szabó.
}

\author{
Archaeopress Roman Archaeology 49. Oxford: Archaeopress, 2018. 241 pp.
}

\section{Péter Kató}

Department of Ancient History, Faculty of Humanities, Eötvös Loránd University, H-1088 Budapest, Múzeum krt.6-8; kato.peter@btk.elte.hu

In spite of important exceptions bridging the two fields, the archaeology of the Roman provinces and the study of Roman polytheistic religion often appear even today as separate disciplines. Archaeologists dedicate most of their efforts to the publication and interpretation of the material brought to light by their excavations. On the other hand, the most innovative scholars of religious history pay more attention to theoretical approaches taken from sociology, anthropology, and religious studies than to collecting and evaluating large bodies of archaeological and epigraphic evidence. More intense dialogue between these two fields has great potential for advancing our understanding of the religious history of the ancient world.

The book under review, Csaba Szabó's doctoral dissertation defended in Erfurt and Pécs, is an attempt to achieve just this. ${ }^{1}$ Szabó aims to analyse the rich epigraphic and archaeological evidence about sanctuaries in Roman Dacia using the questions and methods developed by the Lived Ancient Religion Project (LAR), one of the most innovative research programmes in this field, headed by Jörg Rüpke at Erfurt. As will become clear from the following, Szabó often succeeds in making the epigraphic and archaeological material "speak" about religious experiences in Dacia, even if his reconstructions are not always fully convincing. Szabós approach is made even more important by the fact that much-often very high quality-research on Roman Dacia was published in Romanian, and therefore remains inaccessible to most foreign scholars.

The Introduction (pp. 1-10) presents the main categories and methodological assumptions according to which the material regarding religion in Roman Dacia is analysed. For Szabós work, the most important element and major methodological innovation of the LAR project is the category of "space sacralization", which is used

1 A number of reviews of this book have already appeared. See e.g., Donev, "Sanctuaries in Roman Dacia”; van Haeperen, "Sanctuaries in Roman Dacia”; Moser, "Putting the Sacred into Space." 
instead of the more traditional concepts of "cult place" or "sanctuary". Using the category of space sacralization means focusing on the dynamic aspects of religious communication: places of religious communication are not simply "out there", but need to be created and maintained, and are often abandoned. From this approach, the strategies, possibilities, and limits of space sacralization emerge as intriguing topics of analysis. As Szabó explains, the focus on space sacralization also means that sanctuaries are not the only possible objects of analysis, since a wide range of other places can become the objects of sacralization. Such places include corners on a street where an altar is placed, a courtyard of a house with a cult niche, or even the body of a pilgrim visiting a healing sanctuary. Sacralized places are further divided into primary, secondary, and shared places. Unfortunately, the author only gives a definition of primary sacralized spaces (small, often portable objects in the property of, and used by private individuals; p. 3), while uncovering the meaning of secondary and shared spaces is left to the reader. From the subsequent chapters it seems that secondary sacralized spaces are the sanctuaries, banquet rooms, and gathering places of small religious groups (e.g. the worshippers of Mithras or Iuppiter Dolichenus), whereas shared spaces are the sanctuaries managed by cities: these were often large buildings or complexes visited by a large number of people of often very diverse origin. However, the book is almost completely dedicated to the analysis of secondary and shared sacralized places, with very little attention paid to the first category of sacralized places. Indeed, the author explicitly states that he will not deal with funerary practices and domestic (household) religion, although these topics are of foremost importance in the LAR approach (p.7). ${ }^{2}$

The longest chapter (Chapter 2, pp. 11-127) of the book is dedicated to an analysis of religious life in Apulum (Alba Iulia/Gyulafehérvár). Here, the author offers a detailed analysis of the epigraphic and archaeological evidence on religious life in the fort and civilian settlements (Colonia Aurelia Apulensis, Municipium Septimium Apulense). From the multifaceted analysis, the central role in religious life of the elite, both local and imperial, through the performance of rituals, priesthoods, and financial support for religious infrastructure (euergetism) clearly emerges. Case studies are devoted to the Asklepieion, the sanctuary of Liber Pater, and the cult of Mithras. The close analysis of the archaeological material and the spatial relations between the various small-group sanctuaries allow the reconstruction of the "soundscape" and "sensescape" of the cult places. This is the most stimulating and valuable part of the book. A critical analysis of the archaeological material that supposedly proves the early existence of Christianity in Apulum rounds off the chapter and convincingly argues that most objects cannot be taken as indicators of

2 This choice is justified by the claim that Romanian archaeology concentrated on Limesforschung and urban archaeology—an argument the present reviewer cannot understand. 
the Christian creed. Here, as elsewhere, the author is attentive and laudably critical of the use of ancient evidence for the purposes of identity politics both in modern Hungary and in Romania.

In the short Chapter 3 (pp. 128-140), Porolissum and Praetorium, two settlements with a primarily military character, are analysed. In contrast to what the title of the chapter suggests, however, from the rich religious landscape of these settlements only the sanctuaries of Iuppiter Dolichenus are discussed in detail, with special attention to the interpersonal networks of the soldiers involved in the cult.

The following chapter deals with small rural sanctuaries, with a special focus on the healing sanctuary of Germisara and the mining settlement of Ampelum.

The three main chapters of the book treat a wealth of archaeological and epigraphic material and contain a large number of interesting observations, and the reader sometimes has a hard time following or even finding the main thread. For this reason, the concluding Chapter 5 is expected to bring together the different topics that have emerged in the course of the analysis. This expectation is unfortunately not fulfilled by the conclusions. In this chapter, the main motives of the book are enumerated again. The question of the differences between Dacia and other provinces of the Roman Empire is posed at the end of the book. The answer given to this question is worth quoting:

"The specificity of this province is that Empire-scale infrastructure and connectivity were already well established when it was conquered and led to a much more rapid transmission of religious traditions, which were appropriated in a much more diverse society than in other provincesapparently, with the passive presence and cultural memory of the indigenous Dacians. It seems also that all the visible materiality of Roman religious communication was left by a few hundred people from three or four generations. The religious life of the other hundreds of thousands [is] gone without much in the way of material traces".

This rather simple conclusion does not do justice to the wealth of material analysed in the book.

Szabós book discusses a huge amount of source material and contains a large number of important and interesting observations. However, some points of criticism should also be made. As already mentioned, a structural weakness of the book is that it does not consequently apply the theoretical concepts outlined in the introduction. This leads the author to the counter-intuitive statement that the fort at Apulum was a temple: "The orientation of the fort and their buildings, the urbanlike structure of the internal road system (cardo, decumanus), the presence of the lustratio exercitus and the numerous genii loci suggest that the fort was a templum, a 
privileged area protected by sacral law, with performances and even festivals" (p. 2). However, the presence of religious infrastructure and the performance of religious rituals do not turn a fort into a temple. The concept of space sacralisation could have been useful when describing this phenomenon and in transgressing the dichotomy of sacred vs. secular places.

The use of theoretical concepts taken from religious studies is sometimes not clear enough and seems to be attached to the source material rather mechanically: I admit that I did not always understand the use of these concepts. A case in point is the concept of agency. A simple definition of agency is the ability to provoke change in the world. Research in anthropology and religious studies has shown that not only individuals but institutions, networks of people, and even objects and machines can possess religious agency. ${ }^{3}$ In line with this idea, Szabó supposes that buildings possessed agency in religious communication. One understands that people do not perform their actions in a lifeless and passive scenery, but constantly interact with them, and in this sense a wall, a gate, or a theatre can play a certain role in religious communication (i.e. they have agency). The question is, how did they do this, and what difference did buildings and objects make in religious rituals? Unfortunately, as the author himself admits, the sources from Dacia do not allow one to specify how exactly the walls influenced religious rituals (pp. 16-17): this makes the statement on the agency of walls an unsubstantiated claim. Similarly, I do not see how it furthers our understanding of ancient religion if we ascribe religious agency to simple vessels used in rituals without explaining what exactly constituted the agency of these objects (p. 83). Neither can I understand how "money and power were used consciously as religious agents in some public spaces of Ampelum" (p. 160): it was rather money and power that gave certain individuals religious agency, because the latter could be used to finance dedications and building projects or to attain priesthood and political office.

Another area where I cannot follow Szabó is regarding the application of the concept of individuality to dedications. Szabó is undoubtedly right in using the typology of individuality developed by Rüpke (practical, moral, competitive, representative, reflexive), as it allows a conceptualization of much of individual religious behaviour in ancient polytheism. Regarding the dedications set up by persons who among their other public duties served as priests, Szabó states without any further explanation: "Mentioning the priestly title on the inscription did not mean necessarily also a sacerdotal act, but it was an act of moral religious individuality". While I perfectly agree with the first part of the statement, I cannot see what the reference to a priestly office in a cursus honorum has to do with moral individuality, defined by Rüpke as follows: "Moral individuality involves the ascription of responsibility 
to persons for their own behaviour, concepts of sin and punishment as well as law."4 As far as I can see, a simple reference to a priesthood has nothing to do with this conception of moral individuality.

Szabó has digested and cited an impressive amount of secondary literature. However, he sometimes uses the works he cites in an imprecise way. On p. 142, for instance, he claims that the period of Roman rule in Dacia caused transformation of the natural environment, including massive deforestation. In support of this claim, "Woolf 2012, 48-61" is quoted in fn. 31. Woolf, however, claims that there was no massive deforestation. ${ }^{5}$ In the discussion of the unusual bilingual inscription of $\mathrm{C}$. Sentinus Iustinus from Germisara, "Várhelyi 2013" is cited. This work, however, does not appear in the bibliography, and neither was I able to identify this work in any online resource. Furthermore, Szabó understands this inscription to be the personal creation of Sentinus, and interprets it as a sign of religious individuality. However, "Piso 2015", a paper cited by Szabó himself, argues, in my opinion convincingly, that this text was written by a professional "poet" who offered his services to the visitors of the healing sanctuary at Germisara. This does not mean, of course, that the inscription did not reflect the personal preferences of Sentinus, but deeper engagement with this topic could have enriched the discussion on religious individuality. Analysing the Germisara inscription, Szabó writes about the "metamorphosis" of Sentinus, which is not borne out by the text in any way. To be sure, there are references to healing and an encounter with the divinity, which could be interpreted as a "metamorphosis" of the pilgrim (see the well-known cases of Aelius Aristeides or Lucius in Apuleius's Metamorphoses), but the fact remains that no evidence for this idea can be found in the inscription.

A final remark on the use and translation of the Latin texts is called for. The author cites many inscriptions in the original, without providing a translation. In some cases, his interpretations are false. Regarding the inscription of P. Aelius Theimes, Szabó states that the temple for the Syrian divinities was "rebuilt" by the dedicator, while the text clearly speaks about the construction of the temple (templum fecit). In the same way, in discussing the inscription of Statorius in Apulum, Szabó writes about the reconstruction of the Mithraeum, while the text unmistakably states that the sanctuary was built by Statorius (templum pr[o] / [sal]utem sua suorum / [que p] ecunia mea feci/, p. 105). Even more disturbing are grave grammatical errors in the use of Latin and Greek termini, such as "territorii" (p. 11), "temenoi" (p. 15), "locus sancta" (p. 64), and "carmen latinae” (p. 153).

$4 \quad$ Rüpke, "Individualization and Individuation."

5 Woolf, Rome. An Empire's Story, 61: "Repeated attempts to convict Roman civilization of causing deforestation and soil erosion have failed to convince." 
These criticisms aside, Szabós book is an important contribution to the religious history of Roman Dacia. Readers interested in provincial religion will find here a wealth of relevant source material and a number of valuable observations. The book also shows how the detailed analysis of archaeological and epigraphic remains from a Roman province can be combined with the theoretically informed study of the history of ancient polytheism. It is to be hoped that many further studies will follow Szabós lead.

\section{Literature}

Donev, Damjan. "Sanctuaries in Roman Dacia: Materiality and Religious Experience. By Csaba Szabó.” American Journal of Archaeology 124, no. 4 (2020) doi.org/10.3764/ajaonline1244.Donev

van Haeperen, Françoise. "Sanctuaries in Roman Dacia: Materiality and Religious Experience. By Csaba Szabó.” Bryn Mawr Classical Review 2020.03.26. Accessed 26 November 2021. https://bmcr.brynmawr.edu/2020/2020.03.26/

Moser, Claudia. "Putting the Sacred into Space - Csaba Szabó, Sanctuaries in Roman Dacia: Materiality and Religious Experience." Journal of Roman Archaeology 33 (2020): 817-24. doi.org/10.1017/S1047759420000549

Rüpke, Jörg. "Individualization and Individuation as Concepts for Historical Research." In The Individual in the Religions of the Ancient Mediterranean, edited by Jörg Rüpke. Oxford Scholarship Online (January 2014), Oxford: Oxford Scholarship. doi.org/10.1093/acprof:oso/9780199674503.001.0001

Sax, William S. "Agency." In Ritual und Ritualdynamik, edited by Christiane Brosius, Axel Michaels and Paula Schrode, 25-31. Göttingen: Vandenhoeck \& Ruprecht, 2013.

Woolf, Greg. Rome. An Empire's Story. Oxford: Oxford University Press, 2012. 